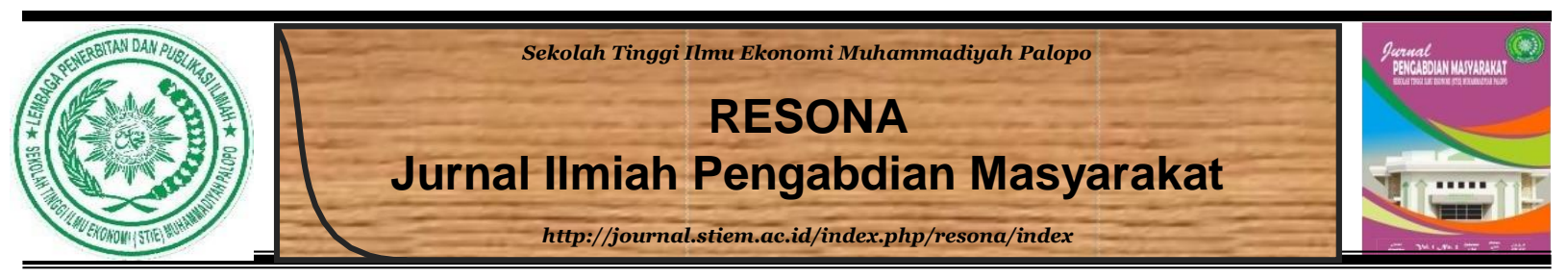

\title{
Sosialisasi Pengemasan Kue Tradisional Di Desa Sepabatu, Kec. Tinambung, Kab. Polewali Mandar
}

\author{
Mujirin M. Yamin ${ }^{1}$, Endriady Edy Abidin², Sulaeman ${ }^{2}$
}

Universitas Sulawesi Barat

\begin{tabular}{l} 
INFO NASKAH \\
\hline Diserahkan \\
20 maret 2018 \\
Diterima \\
25 mei 2018 \\
Diterima dan Disetujui \\
10 Juni 2018 \\
\hline
\end{tabular}

\section{Kata Kunci:}

Sosialisasi, Kemasan dan Label, Desa Sepabatu

\begin{abstract}
ABSTRAK
Tanah Mandar memiliki cukup banyak aset kultural yang bernilai ekonomis baik secara potensi dan bernilai tambah jika dikembangkan lebih jauh. Salah satunya adalah kue-kue tradisional. Kue-kue yang merupakan warisan sosiokultural-historis ini akan menjadi sebuah medium peningkatan pendapatan masyarakat yang baik, dalam hal ini industri rumahan, jika dikelola dan diberikan nilai tambah yang tepat. Nilai tambah yang dapat diberikan dalam konteks pengembangan kewirausahaan dalam konteks pengabdian kepada masyarakat ini adalah sosialiasi dan pelatihan singkat tentang kemasan dan pemberian label. Selain juga dilakukan promosi singkat tentang produkproduk kue setempat kepada tamu yang datang. Pengabdian yang dilakukan mendapat antusiasme yang baik dari pihak pemerintah desa dan masyarakat di Desa Sepabatu. Pengabdian yang dilakukan berupa sosialisasi singkat. Dengan tambahan pengetahuan ini diharapkan masyarakat mendapat asupan wawasan dan pengetahuan dalam memperbaiki kemasan dan label produk yang mereka buat.
\end{abstract}




\section{Pendahuluan}

Secara umum, kemasan dipahami sebagai wadah atau pembungkus yang berguna untuk mencegah atau meminimalisir terjadinya kerusakan pada barang yang dikemas. Bagi banyak kue atau jajanan tradisional, kemasan tersendiri menjadi satu masalah di era modern. Terdapat anggapan bahwa kue tradisional itu kurang keren karena dapat ditemui dengan mudah di pasar tradisional, dikemas seadanya, tanpa kemasan yang apik. Kemasannya yang terkesan murahan dan diidentikan dengan kumuh, tidak higienis, tidak praktis. Konotasi barang murah ini, membuat kue tradisional memiliki market yang tidak dapat menjangkau pasar yang lebih luas atau menjadi produk khas satu daerah. Memang di pasar sudah mulai ditemukan berbagai makanan kue lokal yang namanya muncul dengan merk yang kuat, namun di banyak daerah, kue atau jajanan tradisional masih dalam bentuk kemasan yang tidak berbeda sejak puluhan tahun lalu. Untuk akses pemasaran yang lebih luas, ini menjadi sebuah masalah. Dan kondisi yang serupa juga terdapat di Sulawesi Barat, khususnya Polewali Mandar, yang menjadi lokasi pengabdian masyarakat ini. Desa Sepabatu di Kecamatan Tinambung, Kabupaten Polewali Mandar, menurut kepala desa dan masyarakat setempat, merupakan salah satu sentra pembuatan kue tradisional yang dipasarkan ke sekitar kecamatan Tinambung. Tidak sedikit industri rumahan yang dikelola para ibu rumah tangga bergerak di sektor ini dan menjadi salah upaya masyarakat untuk mendapatkan tambahan penghasilan bagi kebutuhan rumahtangga. Potensi ekonomi yang dimiliki oleh usaha kue tradisional di desa Sepabatu tidak bisa dibilang kecil. Namun dikarenakan pengemasan kue-kue tradisional tersebut masih sangat sederhana, nilai tambah yang seharusnya bisa dihadirkan ketika kue dikemas dengan lebih baik menjadi hilang.

Dalam banyak kasus, nilai tambah sebuah produk menjadi berkali lipat dengan hanya menambahkan kemasan yang menarik. Tidak jarang, yang membedakan laris tidaknya sebuah produk adalah cara pengemasan produk yang dihasilkan. Dengan pengemasan yang lebih baik, produk-produk tersebut dapat berdaya jangkau pemasaran yang lebih luas, tidak hanya di sekitar wilayah produksi, atau dapat dijadikan sebagai oleh-oleh. Pengalaman beberapa orang yang pernah berkunjung ke tanah Mandar, kesulitan ketika ingin membawa kue khas tradisional daerah ini adalah tidak tersedianya pengemasan yang memudahkan dan cantik ketika ingin dibawa bepergian dalam jarak yang jauh.

Pemberian nilai tambah satu produk terkadang bersifat kecil. Namun inovasi yang kecil sekalipun jika dilakukan secara tepat akan memberikan nilai tambah yang signifikan bagi produk yang dihasilkan. Salah satu pertambahan nilai yang mungkin kecil dan tidak mengubah secara 
signifikan produk adalah pemberian kemasan yang baik dan menarik. Pemberian kemasan seperti ini akan memberikan kesan pada produk yang dihasilkan bahwa produsen telah bersungguhsungguh mengolah produk tersebut dengan baik dan penuh perhatian. Dengan begitu produk akan lebih siap untuk dipasarkan dan dijadikan sebagai buah tangan. Kemasan yang baik juga dapat menjadi sarana promosi bagi produk-produk. Dengan melihat kemasan yang menarik, pembeli juga kemungkinan akan membelanjakan uangnya lebih banyak karena keingintahuan mereka pada produk-produk lain yang dihasilkan.

Salah satu yang mungkin juga menjadi nilai tambah bagi kemasan yang baik adalah terbangunnya loyalitas pembeli atau konsumen. Jika konsumen sudah terlanjur menyukai produk yang dihasilkan maka kemungkinan untuk berpindah ke merek yang lain menjadi lebih kecil. Tidak jarang seorang konsumen rela membayar mahal demi sebuah ekspektasi produk. Secara jangka panjang ini akan sangat berguna bagi keberlanjutan usaha atau perusahaan itu sendiri.

Bagi produk-produk kue atau makanan ringan yang dibuat di pabrik, kemasan yang menarik dan unik bukanlah sebuah masalah besar. Kemampuan desain tenaga terampilnya dan kapasitas untuk memproduksi kemasan tersebut tersedia setiap saat. Hal yang berbeda ketika kita sampai pada produk-produk tradisional, yang salah satunya adalah kue khas tradisional. Tidak jarang dijumpai kue-kue ini, yang mungkin dari segi rasa jauh lebih enak dibandingkan produksi pabrik, dibuat oleh industri skala kecil, termasuk industri rumahan, dengan pengetahuan dan kemampuan untuk mendesain kemasan yang terbatas. Sementara jika kita mau melihat lebih dalam, kue tradisional merupakan bagian dari keragaman Indonesia yang lahir dari berbagai perbedaan geografis ruang hidup masing-masing masyarakat, budaya, adat-istiadat, dan tradisi yang berbeda satu dengan yang lain. Berbagai perbedaan ini menjadi karakteristik yang melekat pada kehidupan mereka. Termasuk ke dalamnya makanan dan rupa-rupa jajanan kue tradisonal yang begitu beragam sesuai konteks lokal. Di dalam makanan tradisional tersebut terefleksi sejarah panjang sebuah masyarakat, persentuhan mereka dengan berbagai entitas budaya lain, dan nilai-nilai konstruksi masyarakat setempat.

Dari sudut pandang antropologi budaya, kegiatan makan merupakan salah satu unsur kebudayaan (Noviadji, 2014:12). Semua manusia membutuhkan makanan yang tanpanya tidak akan ada kehidupan. Namun makan sebagai sebuah kontekstualisasi ruang hidup memiliki perbedaan antara satu masyarakat dengan masyarakat yang lain mulai dari menyiapkan bahan makanan, proses memasak, mengemas, hingga proses memakannya (Noviadji, ibid). Menurut Winarno (dalam Noviadji, ibid), 'makanan tradisional adalah makanan yang pekat dengan tradisi setempat'. Makanan ini diolah dari berbagai bahan yang tersedia di atas tanah tempat masyarakat 
tersebut hidup dan diolah dengan tatacara tertentu dengan resep yang tertentu pula secara turuntemurun sesuai dengan selera masyarakat setempat. Itulah sebabnya, makanan tradisional memiliki ciri khas yang berbeda dari satu tempat ke tempat yang lain (Noviadji, ibid).

Makanan tradisional jika dikemas dengan baik akan memberikan prospek ekonomi yang baik pula. Tidak hanya prospek ekonomi, sustainabilitas makanan yang menjadi penanda kebudayaan satu masyarakat ini menjadi begitu penting di tengah hantaman berbagai produk makanan pabrik dan jika tidak dilestarikan akan menghilang seiring berjalannya waktu dan hanya menjadi cerita bagi generasi mendatang. Namun jika dikembangkan dengan baik, ia akan memberikan lapangan pekerjaan bagi banyak orang dan menjadi kebanggaan masyarakat dan daerah tersebut.

\section{Masalah}

Daerah Mandar, di mana lokasi pengabdian merupakan salah satu bagiannya, memiliki banyak penganan tradisional yang bernilai historis, kultural, dan ekonomis baik. Pengamatan yang kami lakukan di beberapa sentra oleh-oleh dan tempat penjualan tradisional, terdapat kecenderungan pengemasan dilakukan secara sangat sederhana dan tidak cukup menarik untuk dibawa bepergian jauh. Padahal, jika melihat lokasi pemasaran yang terdapat di pinggir jalan besar provinsi, jika dikemas dengan baik, produk-produk yang diproduksi dapat menjadi oleholeh khas daerah.

Kondisi serupa juga terjadi di Desa Sepabatu. Desa yang terletak di pinggir selat Makassar ini, dan merupakan bagian dari Kecamatan Tinambung, Kabupaten Polewali Mandar, merupakan salah satu sentra pembuatan kue tradisional etnis Mandar. Sejauh ini, kebanyakan kue-kue tersebut hanya dipasarkan via pasar tradisional, padahal jika melihat potensinya, kue-kue in dapat dipasarkan sebagai oleh-oleh ataupun keluar provinsi. Salah satu yang menjadi persoalan adalah pengemasan mengakibatkan kue-kue tersebut tidak dapat bertahan lama ataupun masih sangat sederhana.

Adanya pengemasan yang baik dapat menjadi media komunikasi dan promosi yang dapat mendongkrak penjualan, karena packaging pada saat ini mengalami pergeseran fungsi yang awalnya hanya melindungi sebuah produk, kini berfungsi sebagai identifikasi sebuah merk dagang Perkembangan packaging akhirnya menjadikan bagian ujung tombak dari promosi suatu produk yang akhirnya berfungsi meningkatkan nilai jual produk.

Produk-produk industri rumahan yang begitu beragam di Sepabatu memerlukan perhatian dalam hal pengemasannya. Sayangnya pengetahuan tentang variasi bentuk kemasan yang menarik dan sesuai dengan fungsinya masih belum dipahami oleh pengusaha kue-kue tradisional, 
seperti yang dituturkan salah seorang penduduk desa bahwa selama ini kualitas kemasan produk kue tradisional di Sepabatu masih cenderung seadanya. Masih banyak pelaku usaha yang belum mengetahui tentang kemasan yang baik dan aman, informasi apa saja yang harus dicantumkan dalam sebuah kemasan, serta teknik pengemasan dan desain kemasan yang menarik. Berdasarkan latar belakang akan pentingnya fungsi kemasan di atas, maka kegiatan pengabdian kepada masayarakat berupa sosialiasi pembuatan kemasan produk kue tradisional ini perlu untuk dilaksanakan, untuk memberikan wawasan desain dan bentuk kemasan baru yang membuat produk menjadi lebih bernilai dan aman.

Berdasarkan pada permasalahan di atas dengan bermitra dengan Pemerintah Desa Sepabatu dan Pengusaha home industry di Sepabatu, dilakukan sosialisasi pengemasan kue-kue tradisional. Ke depannya diharapkan hasil-hasil yang diperoleh dapat memberi manfaat lebih untuk meningkatkan nilai tambah produk kue tradisional masyarakat setempat dan pada gilirannya taraf perenomian masyarakat di Sepabatu.

\section{Metode}

Untuk membantu mengatasi permasalahan yang dihadapi oleh mitra, solusi yang ditawarkan dalam pengabdian kepada masyarakat adalah sebagai sosialisasi pengemasan. Sosialisasi ini nantinya tidak hanya bersifat ceramah tetapi lebih interaktif dengan menggunakan medium bahasa lokal serta menggunakan medium teknologi informasi agar dapat lebih mengena bagi mitra dan mencari model-model inovatif dan kreatif kemasan yang akan diinformasikan. Inti yang akan diperkenalkan kepada masyarakat adalah:

a. Mencari model desain kemasan yang unik. Salah satu point penting dalam membentuk kemasan adalah dengan mendesainnya secara unik, inovatif dan berbeda dari produk lainnya. Kemasan yang unik sangat efektif untuk menarik minat masyarakat dan membuat penasaran.

b. Desain Kemasan Sesuai Target Market. Desain kemasan yang digunakan disesuaikan dengan target pasar.

c. Membuat Kemasan dengan Beberapa Ukuran. Produk yang diusahakan untuk dikemas dengan berbagai ukuran misalnya small, medium dan large.

d. Mencantumkan Informasi Produk Secara Lengkap. Pencantuman informasi produk pada kemasan, misalnya secara standar kemasan mencantumkan komposisi produk, jenis produk, cara penggunaan dan tanggal kadaluarsa. 
Jabaran kegiatan pengabdian kepada masyarakat yang akan dilaksanakan adalah sebagai berikut:

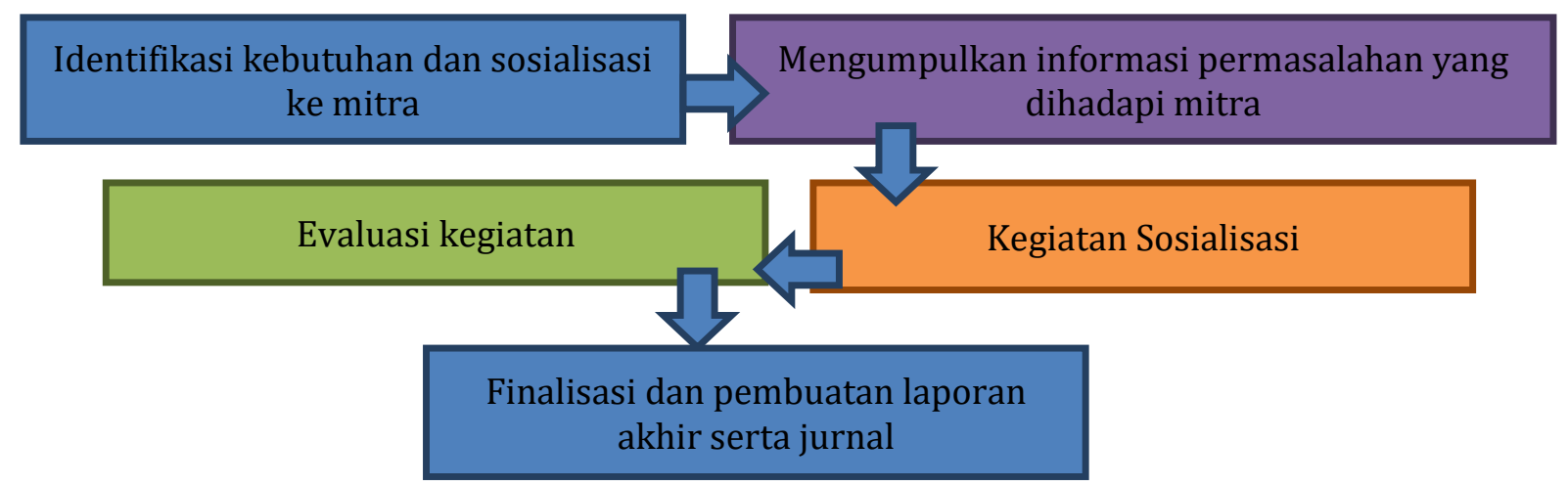

Bagan 1. Alur Kegiatan

Alur dari kegiatan di atas dijelaskan sebagai berikut, yaitu: Pertama, Identifikasi Kebutuhan dan sosialisasi ke mitra. Pada tahapan ini, tim mengidentifikasi langsung segala kebutuhan dan sekaligus menyosialisasikan tentang program PKM ini. Kedua, mengumpulkan informasi permasalahan yang dihadapi mitra. Mengunjungi sentra kerajinan untuk melihat langsung pembuatan produk serta mengumpulkan informasi kemasan yang akan dikreasikan. Ketiga, Sosialisasi. Tahapan ini bertemu dengan mitra peserta pada sebuah forum semi-formal untuk ceramah dan diskusi interaktif tentang pembuatan kemasan produk secara kreatif. Keempat, Evaluasi dan monitoring. Pemetaan hambatan keberlanjutan kegiatan dan solusinya serta penyusunan laporan kemajuan kegiatan Pengabdian Masyarakat. Kelima, Finalisasi Pembuatan publikasi ilmiah dan Laporan Akhir.

\section{Hasil dan Pembahasan}

Secara keseluruhan, rangkaian kegiatan dimulai sejak pra-sosialisasi yaitu tahap persiapan yang dilaksanakan dalam bentuk observasi ke lokasi pengabdian dan diskusi persiapan kegiatan dengan kepala desa Sepabatu. Selanjutnya adalah tahap pelaksanaan kegiatan sosialisasi. Kegiatan sosialisasi pengemasan kue tradisional dilaksanakan dilaksanakan pada tanggal 9 Pebruari 2019 bertempat di aula kantor kepala desa Sepabatu. Peserta sosialisasi adalah selain perangkat desa dan aparat pemerintahan di dusun, hadir juga masyarakat, terutama tokoh masyarakat, yang tertarik untuk mengikuti kegiatan sosialisasi. Mitra sasaran utama sosialisasi yakni para ibu rumahtangga yang menggerakkan industri rumahan produsen kue tradisional Sepabatu juga tidak ketinggalan. Sebagai yang paling berkepentingan dengan sosialisasi ini, ibuibu tersebut bersemangat dalam menghadiri kegiatan. Tahapan akhir adalah evaluasi kegiatan dan preparasi kemungkinan tindak lanjut berikutnya. 
Secara keseluruhan jalannya sosialisasi berjalan dengan sangat baik. Antusiasme peserta hingga berakhirnya acara sangat tinggi. Peserta kegiatan menyadari bahwa kegiatan ini akan sangat bermanfaat bagi usaha yang mereka geluti, pengembangan badan usaha milik desa, dan tentunya kesejahteraan warga desa Sepabatu.

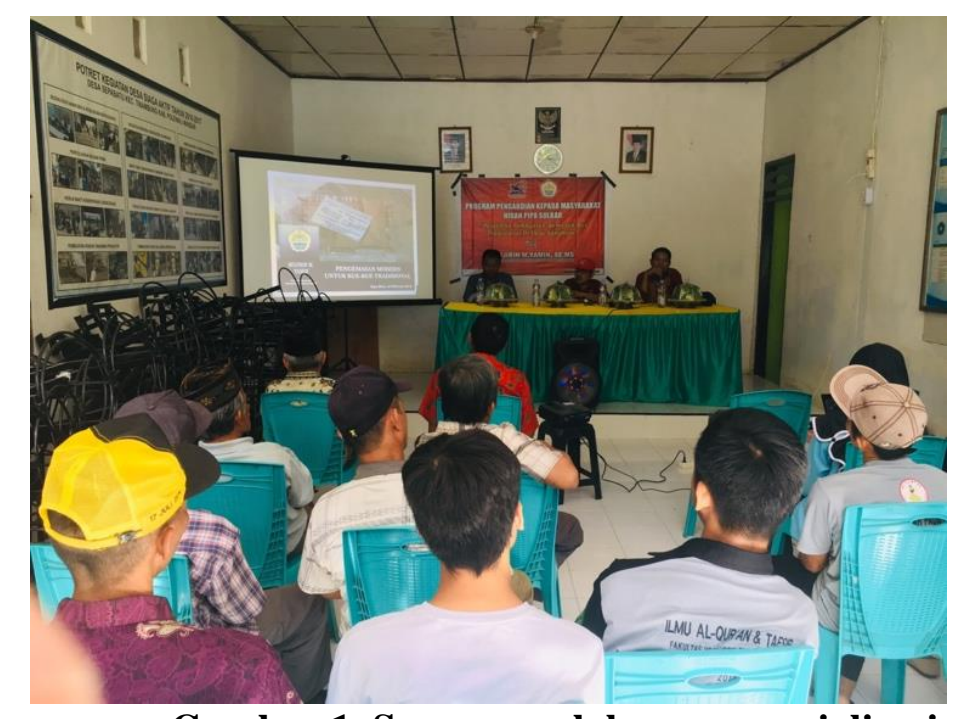

Gambar 1. Suasana pelaksanaan sosialisasi

Pelaksanaan sosialisasi yang sudah dilaksanakan dalam pengabdian ini dapat dipaparkan sebagai berikut :

1. Pemaparan dari kepala desa Sepabatu tentang permasalahan yang dihadapi oleh industri rumahan kue tradisional di desanya. Kepala desa berharap agar nantinya kegiatan ini paling memberikan wawasan yang lebih luas kepada warga, khususnya kepada industri rumahan, agar dapat memberikan nilai tambah bagi produknya. Jika nantinya produk industri rumahan tersebut telah dikemas dengan baik, dapat didistribusikan melalui badan usaha milik desa agar dapat menjadi oleh-oleh bagi yang melintas di jalan raya provinsi atau yang datang berkunjung. Desa sepabatu sendiri sedang mengembangkan potensi desanya termasuk tempat rekreasi. Adanya tempat ini akan saling mendukung dengan industri rumahan kue. Kepala desa juga akan kembali mengundang tim agar memberikan pelatihan, sebagai tindak lanjut dari sosialisasi, agar industri rumahan dapat mempraktekkan langsung pengemasan.

2. Pemaparan dari ketua tim pengabdian. Dalam sesi yang dimoderatori oleh salah seorang yang juga merupakan anggota tim, ketua tim menjelaskan tentang berbagai permasalahan yang dihadapi oleh produk-produk lokal daerah. Daerah boleh memiliki keunggulan dalam cita rasa kue khasnya, tapi ketika pengemasan buruk, potensi ekonomi yang dimiliki oleh produk tersebut cenderung jauh berkurang. Ketua tim juga memaparkan pengalaman ketika mengunjungi berbagai tempat di pulau Jawa yang sangat mengesankan dengan produk- 
produk yang menjadi oleh-oleh khasnya. Salah masalah yang dipaparkan oleh ketua tim adalah sulitnya menemukan kue tradisional di Mandar yang dapat dijadikan buah tangan. Itu terbukti ketika kunjungan anggota DPR dari Jakarta yang hendak membawa pulang oleholeh khas Mandar. Kemasan yang ada sekarang terlalu sederhana untuk dibawa bepergian jauh terutama ketika harus menaiki pesawat terbang. Akhirnya pendamping tim tersebut mengusahakan kemasan yang cukup layak yang didapatkan di ibukota provinsi yang berjarak tiga jam perjalanan dari Sepabatu. Sebuah kondisi yang sangat tidak praktis.

3. Pemaparan selanjutnya dilakukan anggota tim lain yang memberikan pemahaman tentang bagaimana pengemasan kue-kue tradisional dapat dilakukan di industri rumah tangga di Desa Sepabatu. Penjelasan yang diberikan, disertai dengan bantuan slide powerpoint yang sengaja dibuat semenarik mungkin dan sedapat mungkin dipahami, adalah bagaimana cara meningkatkan manajemen wirausaha melalui usaha yang sudah di tekuni selama ini, yaitu mengenai kualitas produk, bagaimana membuat produk yang berkualitas, salahsatunya melalui tampilan kemasan yang cantik sehingga mampu menarik minat masyarakat untuk membeli ataupun membawanya sebagai buah tangan. Juga dipaparkan tentang kemasan yang menarik serta membantu membuat design labelling pada kemasan produk kue basah. Lebih jauh tim memberikan pengetahuan tentang pembuatan kemasan. Dijelaskan bahwa kemasan merupakan salah satu untuk penarik bagi konsumen untuk mau mengeluarkan uangnya membeli produk yang ditawarkan. Semakin baik sebuah kemasan semakin tertarik orang untuk membeli. Untuk itu, kemasan harus terlihat rapi dan tidak secara kasar atau dibuat terburu-buru. Kebanyakan mitra masih menggunakan cara yang sederhana dalam mengemas produknya, yaitu menggunakan kotak plastik yang distapler. Dijelaskan bahwa jika kemasan produk lebih rapi maka produk yang dipasarkan terlihat lebih higienis dan tentunya lebih menarik bagi pembeli. Peserta juga dijelaskan tentang membuat label atau merk yang baik pada kemasan. Label atau merk merupakan ciri unik sebuah produk yang membedakannya satu dengan yang lain. Jadi ketika orang menyebut satu label tertentu, melekat pada label tersebut imajinasi akan kualitas produk yang kita tawarkan. Selain label atau merk, dijelaskan juga tentang apa yang seharusnya terdapat pada sebuah kemasan. Di antara yang dipaparkan adalah informasi tentang bahan-bahan yang digunakan dalam pembuatan produk, alamat produsen, dan kontak yang dapat digunakan konsumen jika ingin membeli atau memesan produk. Tim juga memberikan pengajaran singkat tentang bagaimana mengakses teknologi komunikasi dan informasi untuk memperluas wawasan dan pengetahuan tentang desain kemasan dan akses bahan baku. 


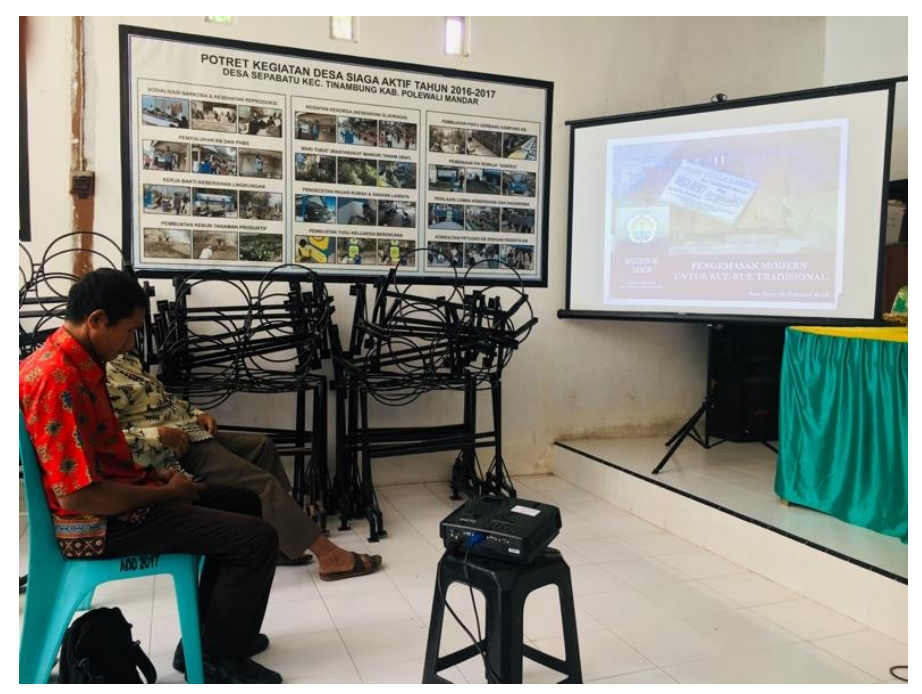

Gambar 2. Slide Presentasi

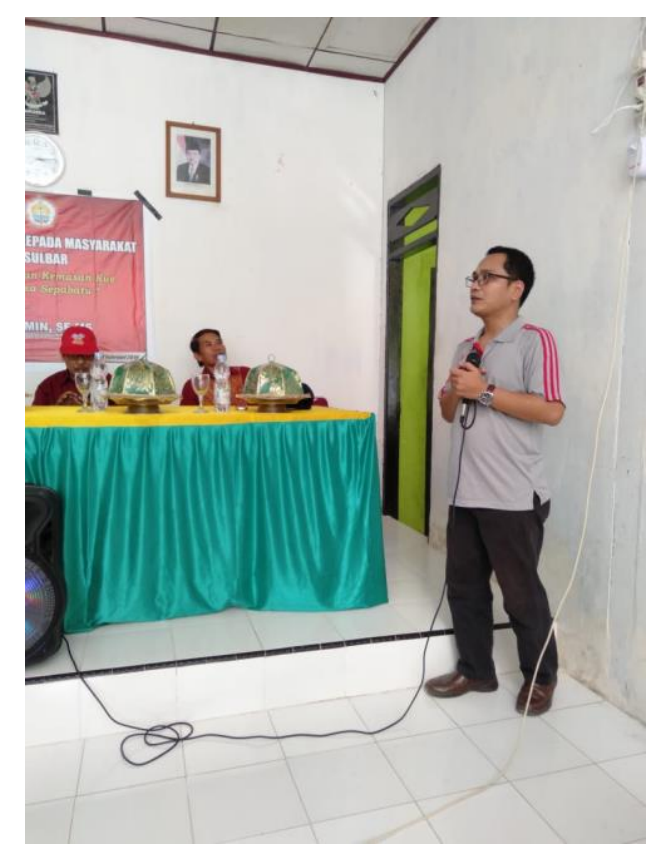

\section{Gambar 3. Pemaparan oleh anggota tim}

Dalam diskusi yang dilaksanakan setelah pemaparan, berbagai usulan menarik bermunculan. Beberapa yang patut untuk diperhatikan sebagai tim sebagai tindak lanjut adalah pemerintah desa mengusulkan pelatihan lebih lanjut yang akan menggunakan dana desa pada tahun ini juga. Selain itu, masyarakat juga meminta dibuatkan pelatihan menggunakan mesin pengemas mengingat bantuan yang diberikan oleh BKKBN tersebut tidak dapat dimaksimalkan dikarenakan ketiadaan kemampuan teknis pengoperasian mesin. Tim dari Universitas Sulawesi 
Barat Pemasaran, juga berkomintmen akan membantu mitra dalam mengenalkan produknya untuk lebih dikenal lagi oleh masyarakat luas melalui tamu-tamu yang berkunjung ke Sulawesi Barat atau Universitas Sulawesi Barat.

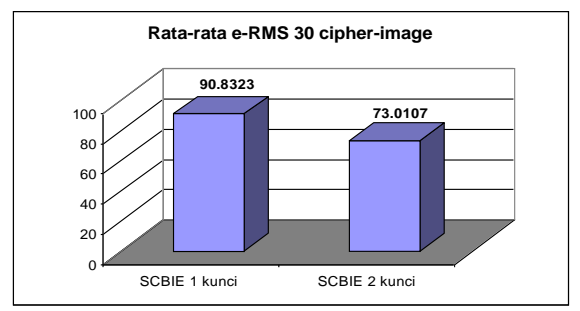

Gambar 1. Grafik Rata-Rata (TNR 10pt)

Tabel 1. Xxxxxxxxxxxxxx (TNR 10pt)

\begin{tabular}{|c|c|c|c|}
\hline $\mathbf{A}$ & B & C & D \\
\hline & & & \\
\hline & & & \\
\hline
\end{tabular}

\section{Simpulan dan Saran}

Kegiatan pengabdian yang dilaksanakan dengan memberikan sosialisasi kepada mitra (aparat desa, masyarakat, dan pemilik home industri kue basah) tentang pentingnya pengemasan yang baik dan menarik. Pengemasan yang baik dan menarik serta pemberian label yang informatif akan meningkatkan keterterikan pembeli untuk produk-produk yang ditawarkan baik untuk dikonsumsi sendiri ataupun sebagai oleh-oleh. Kemasan yang baik akan meningkatkan nilai tambah produk yang pada gilirannya menunjang sustainabilitas usaha home industri kue tradisional selain meningkatkan pendapatan yang lebih baik.

Rekomendasi dari pelaksanaan Pengabdian Pada Masyarakat ini adalah Mitra setelah mendapatkan materi pelatihan tim Pengabdian pada Masyarakat sangat berharap adanya pendampingan kembali dan pelatihan untuk melakukan pengembangan produk lain kue basah. Selain itu dibutuhkan perhatian pemerintah yang lebih luas termasuk di dalamnya pelatihan untuk meningkatkan kompentensi pengusaha kue tradisional.

\section{Ucapan Terima Kasih}

Ucapan terima kasih terhadap Lembaga Penelitian dan Pengabdian Masyarakat (LPPM) Universitas Sulawesi Barat, Fakultas Ekonomi, Sosial, dan Ilmu Politik, Pemerintah Desa Sepabatu, Kec. Tinambung, Kab. Polewali Mandar yang telah memfasilitasi terselenggaranya kegiatan pengabdian pada masyarakat. Demikian, kegaiatan pun dapat berjalan dengan baik dan 


\section{Daftar Pustaka}

Resona Jurnal Ilmiah Pengabdian Masyarakat, (2018)

Noviadji, B. R. (2014). Desain Kemasan Tradisional Dalam Konteks Kekinian. Jurnal Fakultas Desain Vol.1 Nomor 01, 10-21. 